\title{
Global extinction risk for seahorses, pipefishes and their near relatives (Syngnathiformes)
}

\author{
Riley A. Pollom, Gina M. Ralph \\ Caroline M. Pollock and Amanda C.J. Vincent
}

\begin{abstract}
Few marine taxa have been comprehensively assessed for their conservation status, despite heavy pressures from fishing, habitat degradation and climate change. Here we report on the first global assessment of extinction risk for 300 species of syngnathiform fishes known as of 2017 , using the IUCN Red List criteria. This order of bony teleosts is dominated by seahorses, pipefishes and seadragons (family Syngnathidae). It also includes trumpetfishes (Aulostomidae), shrimpfishes (Centriscidae), cornetfishes (Fistulariidae) and ghost pipefishes (Solenostomidae). At least $6 \%$ are threatened, but data suggest a mid-point estimate of $7.9 \%$ and an upper bound of $38 \%$. Most of the threatened species are seahorses (Hippocampus spp.: 14/42 species, with an additional 17 that are Data Deficient) or freshwater pipefishes of the genus Microphis (2/18 species, with seven additional that are Data Deficient). Two species are Near Threatened. Nearly one-third of syngnathiformes (97 species) are Data Deficient and could potentially be threatened, requiring further field research and evaluation. Most species (61\%) were, however, evaluated as Least Concern. Primary threats to syngnathids are (1) overexploitation, primarily by non-selective fisheries, for which most assessments were determined by criterion A (Hippocampus) and/or (2) habitat loss and degradation, for which assessments were determined by criterion B (Microphis and some Hippocampus). Threatened species occurred in most regions but more are found in East and South-east Asia and in South African estuaries. Vital conservation action for syngnathids, including constraining fisheries, particularly non-selective extraction, and habitat protection and rehabilitation, will benefit many other aquatic species.
\end{abstract}

Keywords Aulostomidae, Centriscidae, Fistulariidae, Indo-West Pacific, pipefish, seahorse, Solenostomidae, Syngnathidae

Riley A. Pollom* (Corresponding author, (D) orcid.org/0000-0001-8260-4614) and Amanda C.J. Vincent Project Seahorse, Institute for the Oceans and Fisheries, The University of British Columbia, Vancouver, Canada, and IUCN Species Survival Commission Seahorse, Pipefish and Seadragon Specialist Group. E-mail riley.pollom@gmail.com

GINA M. RALPH IUCN Marine Biodiversity Unit, Department of Biological Sciences, Old Dominion University, Norfolk, USA

Caroline M. Pollock IUCN Red List Unit, Cambridge, UK

${ }^{*}$ Also at: IUCN SSC Global Center for Species Survival, Indianapolis Zoo, Indianapolis, USA

Received 10 December 2019. Revision requested 25 February 2020.

Accepted 31 July 2020. First published online 13 May 2021.
Supplementary material for this article is available at doi.org/10.1017/So030605320000782

\section{Introduction}

Some of the greatest conservation concern for marine life $\checkmark$ arises among species whose habitat most overlaps with that of humans: the neritic species that inhabit shallow coastal zones facing multiple simultaneous pressures (Lotze et al., 2006; Crain et al., 2008, 2009). Anthropogenic impacts on the oceans are often most concentrated here, including exploitation through industrial and artisanal fishing, climate change, coastal development, land-based effluents and pollution, shipping and recreational traffic, habitat destruction from fishing and aquaculture practices, sea-filling and dredging, coastal eutrophication, invasive species and sedimentation. Such pressures have direct impacts on habitats such as estuaries (Waltham \& Connolly, 2011), mangroves (Polidoro et al., 2010), coral reefs (Carpenter et al., 2008), kelp forests (Krumhansl et al., 2016), sponges (Harasti et al., 2014), and seagrasses (Waycott et al., 2009; Short et al., 2011). Unsustainable fishing combined with habitat degradation and loss have a significant and often synergistic impact on fishes, and can lead to local extinctions and increased global risk (Dulvy et al., 2003; Hutchings \& Reynolds, 2004; Reynolds et al., 2005; Crain et al., 2008; Webb \& Mindel, 2015).

The IUCN Red List of Threatened Species is the most widely used method for assessing the extinction risk of species. It has been published since 1964, with regular updates, and is used globally by governments, businesses, management agencies, international environmental agreements, and NGOs to inform conservation action. Its quantitative methods, which include explicit analyses of a species' intrinsic biological features and the pressures bearing on them, have been used to assess $>120$,000 species (IUCN, 2020).

For each taxon, the first IUCN species assessments serve as baselines against which future reassessments will be compared. Such comparisons are used to produce the Red List Index, which measures aggregate genuine changes in the Red List category of species within a taxonomic group (Butchart et al., 2005, 2007, 2010; Stuart et al., 2010). The Red List Index is used to highlight concerns about species that are declining in status and, conversely, highlight successes where conservation action has improved the status of species (Hoffmann et al., 2010, 2015). 
Taxonomic comprehensiveness of the IUCN Red List and improvements in the Red List Index contribute directly to progress on several of the Aichi Biodiversity Targets (CBD, 2010) and UN Sustainable Development Goals (Aichi Targets 6 and 12 on sustainable fisheries and improving species conservation status, and UN Sustainable Development Goal 14 on conserving the oceans, respectively), and are essential for effective species conservation planning and action.

Some of the first marine fishes assessed on the IUCN Red List, in 1996, were the iconic seahorses (Hippocampus spp.). Apart from their intrinsic worth, flagship species such as seahorses have been shown to draw attention and finance towards conservation initiatives (Bowen-Jones \& Entwistle, 2002; Walpole \& Leader-Williams, 2002; Rodrigues \& Brooks, 2007; Shokri et al., 2009; Caro, 2010; Bennett et al., 2015; Carrizo et al., 2017; Stiller et al., 2017).

Seahorses and their relatives are charismatic fishes that have garnered attention and reverence in human cultures for many centuries (Scales, 2009; Lourie, 2016), and thus have the potential to help drive contemporary conservation efforts for coastal ecosystems (Shokri et al., 2009; Vincent et al., 2011; Stiller et al., 2017). Seahorses and many pipefishes are much sought after for traditional medicine, aquarium display and curios. A better understanding of the conservation status of these flagship animals will allow the mobilization of conservation action for a diversity of coastal ecosystems. The Syngnathiformes, as a group, have a circumglobal range that spans coasts everywhere except for polar regions. They live in an array of habitats, including estuaries, mangroves, seagrasses, coral and rocky reefs, kelp forests, sand or mud substrates, streams, lakes and rivers (Dawson, 1985; Foster \& Vincent, 2004; Kuiter, 2009; Lourie, 2016; De Brauwer et al., 2017). Effective conservation of syngnathiform fishes entails a range of conservation actions in coastal areas, many of which are under substantial human pressure (Halpern et al., 2015; McClanahan et al., 2015).

Here we synthesize assessments of the global extinction risk of the Syngnathiformes, drawing on individual species assessments based on the IUCN Red List Categories and Criteria (IUCN, 2020). This is the first time the order has been treated comprehensively, with only $18 \%$ of known species having been evaluated prior to 2017. These assessments will be of value in guiding conservation efforts and provide a baseline for a future Red List Index analysis of Syngnathiformes.

\section{Methods}

\section{Taxa included in this study}

The order Syngnathiformes (Class Actinopterygii) comprises five (formerly six) families of uniquely specialized fishes: Aulostomidae (trumpetfishes), Centriscidae (shrimpfishes), Fistulariidae (cornetfishes or flutemouths), Solenostomidae (ghost pipefishes), and Syngnathidae (seahorses, pipefishes and seadragons; Plate 1) (Longo et al., 2017). Our phylogenetic and taxonomic paradigm for the order largely follows that of Nelson et al. (2016). We do not include in this assessment the Dactylopteridae (flying gurnards), Callionymidae (dragonets), Mullidae (goatfishes) or Pegasidae (seamoths) as evidence for their inclusion within the Syngathiformes is mixed (Kawahara et al., 2008; Wilson \& Orr, 2011; BetancurR. et al., 2013; Near et al., 2013; Song et al., 2014; Sanciangco et al., 2016). Longo et al. (2017) consider these groups to belong to a benthic-associated sister clade that is closely related to, but not a part of, the order Syngnathiformes. In addition, we do not include the Gasterosteiformes (sticklebacks), a distinct order that formerly included families now within the Syngnathiformes (Sanciangco et al., 2016; Longo et al., 2017).

We arrived at a final list of syngnathiform fishes that included 300 extant species at the time of project completion (early 2017; Supplementary Table 1). Of these, 258 are largely restricted to marine waters and 42 inhabit brackish and/ or freshwater. Considerable taxonomic uncertainty remains within the order. We used morphological and/or molecular evidence to define valid species, and rejected putative species differentiated only by variations in colour pattern. During this research several new syngnathid species have been described and their Red List assessments are forthcoming (e.g. Short et al., 2020). Comprehensive treatments of taxonomy are available for the Aulostomidae (Bowen et al., 2001) and the Syngnathidae at the generic level (Hamilton et al., 2017). The most recent reviews of the majority of pipefish genera (Syngnathidae) were undertaken by Dawson (Poss \& Heal, 1994), and we used his subsequent book on the Indo-Pacific pipefishes to inform taxonomic decisions for the pipefishes in that region (Dawson, 1985). The genus Hippocampus (seahorses) was recently revised at the species level (Lourie et al., 2016).

\section{The IUCN Red List assessment process}

Assessments for all species were carried out by the globally designated expert group for this taxon, the IUCN Species Survival Commission Seahorse, Pipefish and Seadragon Specialist Group. Project Seahorse, which acts as the core of this Specialist Group, carried out the assessments, with undergraduate volunteers assisting with data collection. We consulted experts, including fisheries and conservation biologists, government fisheries managers and members of the Specialist Group during the assessment process, and many are either assessors or reviewers of the species assessments. Information for the assessments was obtained from peer-reviewed and grey literature, online databases (Froese \& Pauly, 2019; Fricke et al., 2020; GBIF, 2020; Biodiversity Heritage Library, 2021; Encyclopedia of Life, 


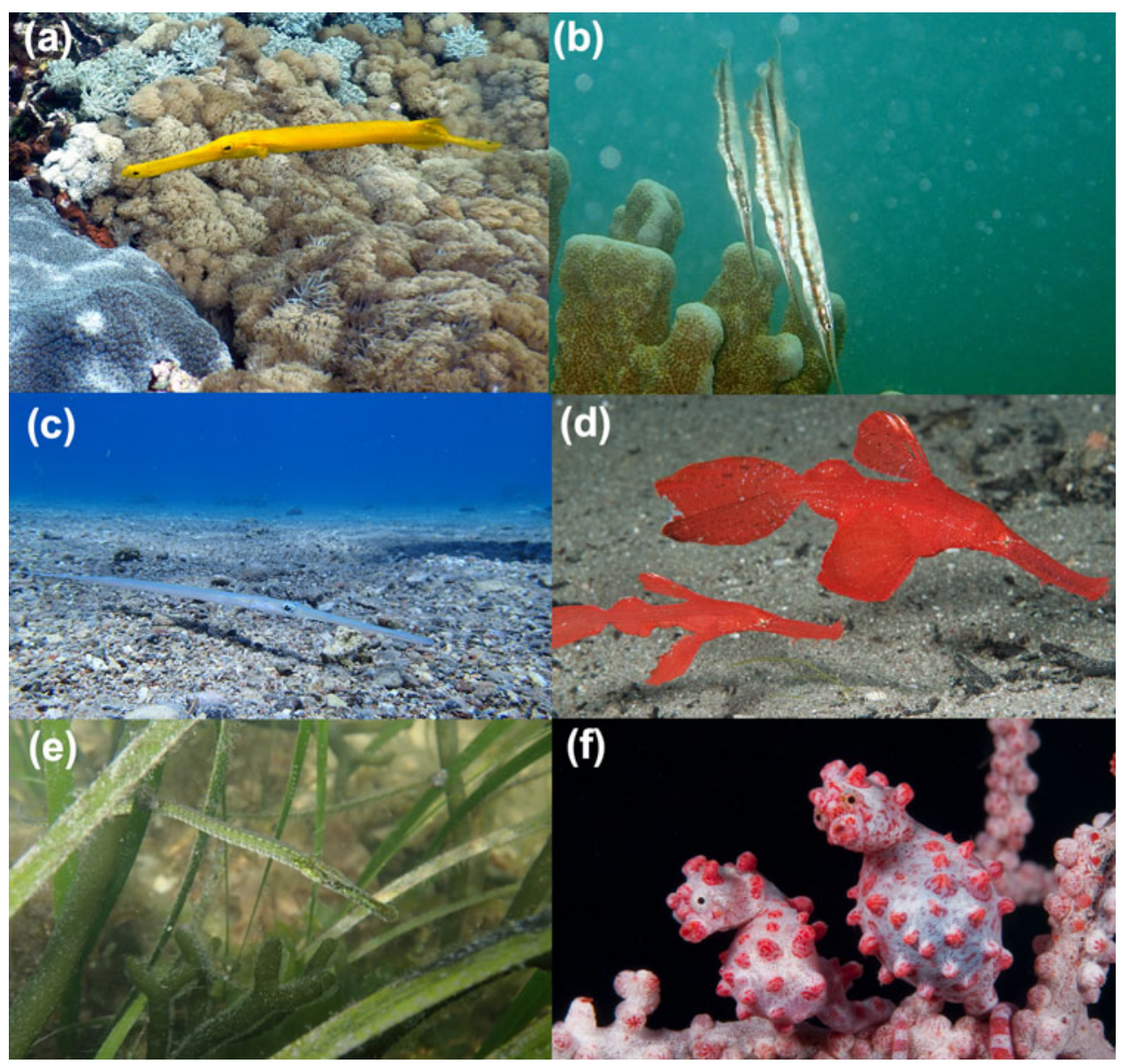

Plate 1 Representatives of all five extant syngnathiform families. (a) Aulostomidae: Pacific trumpetfish Aulostomus chinensis, northern Nusa Penida, Bali, Indonesia (bja28oodk/iNaturalist). (b) Centriscidae: speckled shrimpfish Aeoliscus punctulatus, Toliara, southwest Madagascar (Carmelo López Abad/iNaturalist).

(c) Fistulariidae: bluespotted cornetfish Fistularia commersonii, northern Gulf of Aqaba (Rachel Andres-Beck/iNaturalist). (d) Solenostomidae: robust ghost pipefishes Solenostomus cyanopterus, Komodo, East Nusa Tenggara, Indonesia (Richard Smith/

OceanRealmImages.com). (e) Syngnathidae: broadnosed pipefish Syngnathus typhle, Faro, Portugal (Carmen B. de los Santos/iNaturalist). (f) Syngnathidae. Bargibant's pygmy seahorse Hippocampus bargibanti, Wakatobi, Southeast Sulawesi, Indonesia (Richard Smith/ OceanRealmImages.com).

2021), and from a diversity of experts, including fisheries managers, seahorse traders, biologists, citizen scientists and divers.

The evidence used to inform each assessment includes data on the species' taxonomy, geographical range, population size and trends in abundance, habitats and ecology (especially life history characteristics), anthropogenic threats, conservation actions (those that have been taken as well as those that are needed) and research needs. The latter two items are particularly important for follow-up conservation and research initiatives for threatened and Data Deficient species, respectively.

The IUCN Red List requires species to be assessed as Least Concern (species that are widespread and abundant), Data Deficient (insufficient data available to properly assess extinction risk), Near Threatened (close to qualifying for a threatened category), or threatened. Threatened species fall into one of three categories: Vulnerable (facing a high risk of extinction in the wild), Endangered (facing a very high risk of extinction in the wild), or Critically Endangered (facing an extremely high risk of extinction in the wild). Species can also be assessed as Extinct in the Wild or Extinct (IUCN, 2012). Species assessed as Data Deficient may or may not be of conservation concern, and further research and/or analyses are required to make a valid assessment of extinction risk. Species are assessed as Data Deficient if there are plausible threats but insufficient data to categorize the species reliably as threatened or Near Threatened. Species with no known threats can be assessed as Least Concern regardless of a lack of population data.

Species are assessed for inclusion in one of the IUCN Red List categories using a series of quantitative thresholds that are embedded within five Red List criteria (IUCN, 2012). These include (1) estimates of population size reduction (criterion A); (2) geographical range size (in the form of either extent of occurrence, EOO, or area of occupancy, AOO) and fragmentation or few locations, continuing decline and/or extreme fluctuation (criterion B); (3) small population size and continuing decline (criterion $C$ ); and (4) very small or restricted population (criterion D). Assessors can also use (5) quantitative analysis (criterion E) to project future risk of extinction (such as with a population viability analysis; Boyce, 1992; Frankham et al., 2014), but as data were not sufficient to undertake this task for syngnathiformes, we did not use criterion E. IUCN regularly updates its Guidelines for Using the IUCN Red List Categories and Criteria as new 
scenarios of extinction and risk are encountered (Mace et al., 2008; IUCN Standards and Petitions Subcommittee, 2017).

In our assessments we created species distribution maps by drawing a polygon around known occurrences and trimming this layer to a base data layer that extends to the $200 \mathrm{~m}$ depth contour or a $100 \mathrm{~km}$ buffer from the coastline, to encompass all of the coastal areas potentially inhabited by syngnathiform fishes (e.g. Sanciangco et al., 2013; Comeros-Raynal et al., 2016). These maps are intended only for visualization on the IUCN Red List and represent the area along the coastline where a species occurs, rather than depicting the actual areas and depths inhabited by the species; this approach may exaggerate the extent of species' distribution in some areas and was not used for calculations of EOO to determine extinction risk under criterion B.

Once completed, assessments were then further reviewed by the IUCN Marine Biodiversity Unit, which conducts the Global Marine Species Assessment, and returned to us for revision. Finally, assessments went through a consistency check with the IUCN Red List Unit, before being published. All of these assessments took place during 2013-2017 and are available along with associated spatial data (IUCN, 2020).

\section{Results}

This study provides a first comprehensive synthesis of extinction risk for 300 species of syngnathiform fishes. Globally, 18 of these species are threatened with extinction but many more may also be at risk. A single species, Syngnathus watermeyeri, is assessed as Critically Endangered (0.3\%), three as Endangered (1\%), and 14 as Vulnerable (5\%; Tables $1 \& 2$ ), and the most threatened species occur in the Indo West Pacific (Table 3). However, 97 species (32\%) were assessed as Data Deficient, indicating the total number of Syngnathiformes that are threatened will almost certainly be higher than the currently known $6 \%$. If all Data Deficient species are threatened, this would be $38 \%$ of syngnathiform species. If Data Deficient species are as threatened, proportionately, as species currently known to be threatened, then a mid-point of c. 7.9\% of Syngnathiformes would be threatened. In addition, two species were assessed as Near Threatened. The remaining 183 species (61\%) were assessed as Least Concern; for these species, there were either no known threats affecting the species, or reductions in population size that were not severe enough to meet thresholds under criterion A despite the presence of known threats. Overall, the primary threats to syngnathiform fishes are incidental capture in industrial trawl fisheries (marine species) and habitat loss and degradation through natural system modifications and pollution (freshwater species) (Fig. 1). Pollution is only a minor, secondary threat for the marine species assessed here.
The threatened and Data Deficient species were concentrated in two groups: the marine/estuarine seahorses (Hippocampus spp.) and the predominantly fresh/brackishwater pipefishes of the genus Microphis (Table 1). Fourteen of the 42 seahorse species (one-third) were assessed as threatened, and a maximum of 31 species could be threatened (two Endangered, 12 Vulnerable and 17 Data Deficient). Among the pipefishes, two of the 18 Microphis species were considered to be threatened, with a potential of nine species at risk (one Endangered, one Vulnerable and seven Data Deficient). All but one of the threatened and Near Threatened marine seahorses (14/15) are assessed as such under criterion A (population size reduction), with only one species considered threatened under criterion B (geographical range size). Three of five of the threatened or Near Threatened freshwater pipefishes were assessed as such under criterion $\mathrm{B}$, and one of these species qualified under both criteria $\mathrm{A}$ and $\mathrm{C}$ (Table 1). Other genera for which data are not yet available but that may include threatened species are the Aeoliscus centriscids (2/2 species Data Deficient) and the pipefishes in Doryichthys (5/5), Minyichthys (3/4), Siokunichthys (6/6) and Solegnathus (4/5), and the speciose Syngnathus (15/32).

\section{Discussion}

This first comprehensive assessment of extinction risk in syngnathiform fishes shows that $39 \%$ of species are likely to require attention in the form of management and conservation intervention (for threatened and Near Threatened species) and/or further research (for Data Deficient species), and $61 \%$ are categorized as Least Concern. The most threatened species fall into two groups: (1) marine species under high pressure from fishing, and (2) species in fresh- and transitional waters facing habitat degradation. This pattern is common for aquatic species, with fishing being the biggest threat to generalist, wide-ranging marine taxa, and habitat degradation threatening specialist, endemic freshwater species (Arthington et al., 2016).

For syngnathids, the first group of concern comprises a suite of marine species (most notably the seahorses) that are extracted primarily as bycatch in indiscriminate fisheries (although sometimes also targeted specifically), at levels that drive declines in the number of mature individuals (Perante et al., 2002; Baum \& Vincent, 2005; Meeuwig et al., 2006; O'Donnell et al., 2010; Perry et al., 2010; Vincent et al., 2011). These declines are exacerbated by habitat loss through coastal development, destructive fishing practices and the impacts of climate change (Hughes et al., 2009; Vincent et al., 2011; Harasti, 2016). Habitat degradation and loss tend to worsen the effects of fishing pressure (e.g. Harasti, 2016). As is indicated by the predominance of the threatened species in this group being assessed as such under criterion 
TABLE 1 Syngnathids assessed as threatened or near threatened, the regions they inhabit, and their Red List category and the criteria (IUCN, 2012) used for assessment.

\begin{tabular}{|c|c|c|c|}
\hline Species & $\operatorname{Region}(\mathrm{s})^{1}$ & Red List category ${ }^{2}$ & Criteria \\
\hline Syngnathus watermeyeri & WIO/Africa FW (S. Africa) & CR & $\mathrm{C} 2 \mathrm{a}(\mathrm{i}) \mathrm{b}$ \\
\hline Hippocampus capensis & WIO/Africa (S. Africa) & $\mathrm{EN}$ & $\mathrm{B} 1 \mathrm{ab}(\mathrm{iii}, \mathrm{v})+2 \mathrm{ab}(\mathrm{iii}, \mathrm{v})$ \\
\hline Hippocampus whitei & SWP & EN & $\mathrm{A} 2 \mathrm{bc}$ \\
\hline Microphis pleurostictus & Asia FW (Philippines) & EN & B2ab(iii) \\
\hline Cosmocampus balli & $\mathrm{ECP}$ & VU & $\mathrm{B} 1 \mathrm{ab}(\mathrm{iii})+2 \mathrm{ab}(\mathrm{iii})$ \\
\hline Hippocampus algiricus & ECA & VU & $\mathrm{A} 2 \mathrm{~cd}+4 \mathrm{~cd}$ \\
\hline Hippocampus barbouri & WCP & VU & $\mathrm{A} 2 \mathrm{~cd}$ \\
\hline Hippocampus comes & WCP, EIO & VU & $\mathrm{A} 2 \mathrm{bd}+4 \mathrm{bd}$ \\
\hline Hippocampus erectus & NWA, WCA & VU & $\mathrm{A} 2 \mathrm{~cd}$ \\
\hline Hippocampus histrix & WIO, EIO, NWP, WCP, ECP & VU & $\mathrm{A} 2 \mathrm{~cd}+4 \mathrm{~cd}$ \\
\hline Hippocampus ingens & ECP & VU & $\mathrm{A} 2 \mathrm{~cd}$ \\
\hline Hippocampus kelloggi & WIO, EIO, NWP, WCP, ECP & VU & $\mathrm{A} 2 \mathrm{~cd}$ \\
\hline Hippocampus kuda & EIO, NWP, WCP, SWP, ECP & VU & $\mathrm{A} 2 \mathrm{~cd}+3 \mathrm{~cd}+4 \mathrm{~cd}$ \\
\hline Hippocampus mohnikei & EIO, NWP, WCP & VU & $\mathrm{A} 2 \mathrm{~cd}+4 \mathrm{~cd}$ \\
\hline Hippocampus patagonicus & SWA & VU & $\mathrm{A} 2 \mathrm{~cd}$ \\
\hline Hippocampus spinosissimus & EIO, NWP, WCP & VU & $\mathrm{A} 2 \mathrm{~d}$ \\
\hline Hippocampus trimaculatus & EIO, NWP, WCP & VU & $\mathrm{A} 2 \mathrm{bcd}+4 \mathrm{bcd}$ \\
\hline Microphis insularis & Asia FW (Andaman Islands) & VU & B1ab(iii) \\
\hline Hippocampus reidi & NWA, WCA, SWA & NT & $\mathrm{A} 2 \mathrm{~d}+4 \mathrm{~d}$ \\
\hline Microphis deocata & Asia FW (India) & NT & $\mathrm{A} 2 \mathrm{~cd}$ \\
\hline
\end{tabular}

${ }^{1}$ ECA, Eastern Central Atlantic; ECP, Eastern Central Pacific; EIO, Eastern Indian Ocean; NWA, Northwest Atlantic; NWP, Northwest Pacific; SWA, Southwest Atlantic; SWP, Southwest Pacific; WCA, Western Central Atlantic; WCP, Western Central Pacific. FW, species that predominantly inhabit freshwater.

${ }^{2} \mathrm{CR}$, Critically Endangered; EN, Endangered; VU, Vulnerable; NT, Near Threatened.

A, marine seahorses suffer population declines from fishing pressure and habitat degradation, despite their sizeable ranges (with patchy populations).

The second group of concern comprises many fresh- and brackish-water species that are threatened or Data Deficient. Many of these species are restricted to a few rivers, watersheds or estuaries (Reynolds et al., 2005; Kopf et al., 2017) and such systems are often among the most degraded and threatened from anthropogenic pressures (Dudgeon et al., 2006; Carpenter et al., 2011). The often close proximity of people to rivers and lakes results in eutrophication, industrial and domestic pollution, damming and flow alteration, riparian housing and commercial developments, dredging and canalization (Carvajal-Quintero et al., 2017). Syngnathiform fishes that are restricted to rivers and lakes tend to have smaller range sizes than their marine counterparts, and are thus exposed to multiple, often acute stressors. It is, therefore, perhaps not surprising that three of the five species of conservation concern in this group were recognized as threatened under criterion B. Only one freshwater pipefish is of concern as a result of population reduction (criterion A). The only seahorse assessed as threatened under criterion $\mathrm{B}$ is the Knysna seahorse Hippocampus capensis, which is associated with estuaries and restricted to a small area of South Africa. The most threatened syngnathiform fish is the freshwater pipefish Syngnathus watermeyeri, which occurs in the same region and faces similar threats; it is assessed as Critically Endangered under criterion $\mathrm{C}$ because of its small population size, a decline in the number of mature individuals, and extreme fluctuations.

Although threatened species occur in most regions, we note the higher numbers of threatened syngnathiform fishes in East and South-east Asia, a region with a high number of species that experiences intense fishing pressure and high demand for local and international trade (Table 3). The proportion of threatened species is also high in the South-east Atlantic. Despite this region's lack of diversity in syngnathiform fishes, a few species are threatened by restricted range size and estuarine degradation in South Africa.

Action is needed to determine the conservation status of the one-third of Syngnathiformes species that are currently assessed as Data Deficient. Although there are only limited data for all of the species assessed here, those species assessed as Data Deficient are of special concern. We generally assessed species as Least Concern when we could not identify major threats to the species, even when the available data were poor. We labelled species as Data Deficient when they were little studied and (1) subject to threats that may be causing declines (potential to be assessed as threatened under criterion A upon further investigation), or (2) their range could be small enough for the species to qualify as threatened under a restricted-range criterion (criteria $\mathrm{B}$ and $\mathrm{D}_{2}$ ) but they are under-surveyed, rare, and/or hard to detect. We can infer that some Data Deficient species are 
TABLE 2 Examples of syngnathiform fishes assessed in each of the IUCN Red List categories, with rationale.

\begin{tabular}{|c|c|c|}
\hline Species & $\begin{array}{l}\text { Red List } \\
\text { category }^{1}\end{array}$ & Rationale \\
\hline $\begin{array}{c}\text { Estuarine pipefish } \\
\text { S. watermeyeri }\end{array}$ & CR & $\begin{array}{l}\text { Endemic to three estuaries in South Africa \& dependent on regular freshwater influxes. Threatened by } \\
\text { habitat degradation \& loss from riparian development \& water diversion \& mismanagement. Had not } \\
\text { been found in recent surveys } \& \text { there may be }<250 \text { mature individuals remaining. The population } \\
\text { undergoes large fluctuations \& it is suspected there are }<50 \text { individuals in each subpopulation. Urgent } \\
\text { habitat protection \& water management measures ensuring that minimum environmental flow rates } \\
\text { are similar to natural flow regime are needed to secure this species. }\end{array}$ \\
\hline $\begin{array}{l}\text { White's seahorse } \\
\text { Hippocampus } \\
\text { whitei }\end{array}$ & $\mathrm{EN}$ & $\begin{array}{l}\text { A coastal species endemic to eastern Australia; inhabits seagrasses, macroalgae \& corals in waters that } \\
\text { are heavily impacted by habitat degradation \& loss from coastal development, pollution, sedimentation } \\
\& \text { destructive anchoring of recreational vessels. In some areas where the species was formerly common } \\
\text { it has declined by }>90 \% \text {; in other areas with a smaller proportion of the population it has declined less } \\
\text { or is stable, particularly in marine reserves. Overall decline suspected to be } 50-70 \% \text { over the previous } \\
\text { three generations ( }<10 \text { years). }\end{array}$ \\
\hline $\begin{array}{l}\text { Hedgehog seahorse } \\
\text { Hippocampus } \\
\text { spinosissimus }\end{array}$ & VU & $\begin{array}{l}\text { A coastal seahorse that inhabits soft-bottom reef systems from India \& Sri Lanka to Papua New Guinea, } \\
\text { caught as bycatch in multiple artisanal \& industrial gear types. Declines in the late } 1990 \text { s \& early } 2000 \text { s, } \\
\text { combined with high levels of ongoing exploitation \& trade \& increasing fishing in the region led to } \\
\text { substantial conservation concern. Overall decline suspected to be } 30-50 \% \text { over the previous } 10 \text { years. }\end{array}$ \\
\hline $\begin{array}{l}\text { Smalljaw pipefish } \\
\text { Micrognathus } \\
\text { erugatus }\end{array}$ & $\mathrm{DD}$ & $\begin{array}{l}\text { A coastal Western Atlantic species known only from its type locality (a rock tide pool) in Bahia, Brazil. } \\
\text { Little is known about the species' biology. Threats are unknown, \& research is needed to determine } \\
\text { population status \& trends in abundance. }\end{array}$ \\
\hline $\begin{array}{l}\text { Deocata pipefish } \\
\text { Microphis } \\
\text { deocata }\end{array}$ & NT & $\begin{array}{l}\text { A freshwater species endemic to the Ganges \& Brahmaputra River Basins in South Asia, which are } \\
\text { heavily impacted by anthropogenic flow alterations, damming \& wetland conversion. Sedimentation, } \\
\text { pollution \& overfishing also threaten lacustrine ecosystems in the region, \& there are anecdotal reports } \\
\text { of declines in the Brahmaputra Basin. Although little is known about population size or trends, it can be } \\
\text { inferred from ongoing threats \& reported declines that the species has undergone a decline of } 20-30 \% \text {. }\end{array}$ \\
\hline $\begin{array}{l}\text { Bluestripe pipefish } \\
\text { Doryrhamphus } \\
\text { excisus }\end{array}$ & LC & $\begin{array}{l}\text { The most widespread syngnathiform fish, inhabiting coastal waters from East Africa throughout the } \\
\text { Indian \& Pacific Oceans to Western North \& South America. A habitat generalist, inhabiting both coral } \\
\text { \& rocky reefs. May be affected by localized coral habitat degradation, but is widespread \& able to utilize } \\
\text { other habitat types. Although little is known about population size or trends, it can be inferred that it is } \\
\text { not likely to be at risk of extinction. }\end{array}$ \\
\hline
\end{tabular}

${ }^{1}$ CR, Critically Endangered; EN, Endangered; VU, Vulnerable; DD, Data Deficient; NT, Near Threatened; LC, Least Concern.

${ }^{2}$ Surveys after we concluded our assessment have located the species (L. Claassens, unpubl. data, 2020).

likely to be threatened. For example, the threats to the freshwater Doryichthys species assessed as Data Deficient are similar to those affecting the freshwater Microphis species that we know to be threatened (riparian habitat degradation, pollution and flow diversion), and their life history is comparable. Other Data Deficient species are assessed as such because little was known about the level of mortality that fisheries cause across their range. Research is urgently needed to properly evaluate the conservation status of the Data Deficient species; work could also be done to predict the status of Data Deficient species in the absence of additional data (Bland et al., 2017; Kindsvater et al., 2018; Zhang \& Vincent, 2019).

The Syngnathiformes fall towards the middle of the extinction risk spectrum compared to other orders of fishes (Supplementary Fig. 1). It is likely their life history traits (i.e. low fecundity, extreme parental care and high site fidelity) make them more susceptible to threats than broadcast spawners such as the sardines and herrings (Clupeiformes) or the cods (Gadiformes). On the other hand, some of the larger, less fecund species such as the sawfishes (Pristidae), angel sharks (Squatiniformes), and sturgeons (Acipenseriformes) have life histories that make them more susceptible to threats, in particular targeted fisheries and bycatch.

Our assessment suggests that only $60 \%$ of species are secure (i.e. Least Concern). The vast capture of seahorses, which supplies trade for traditional medicines, aquarium display and souvenirs, is a cause for concern. Our assessments provide a baseline against which to compare future assessments, which will eventually facilitate the determination of an IUCN Red List Index for this group. Because of the high number of species assessed as Data Deficient and the absence of genuine shifts in status for species that had previously been assessed, the calculation of the Index is not currently feasible.

Two classes of remedial action are needed for syngnathids: limiting fishing pressure and protecting habitat, with monitoring and evaluation. The IUCN Red List flags species that require attention and helps in setting priorities. Although it has no automatic implications for management and policy, the Red List provides information for managers and policy-makers. In this context, periodic reassessment of 


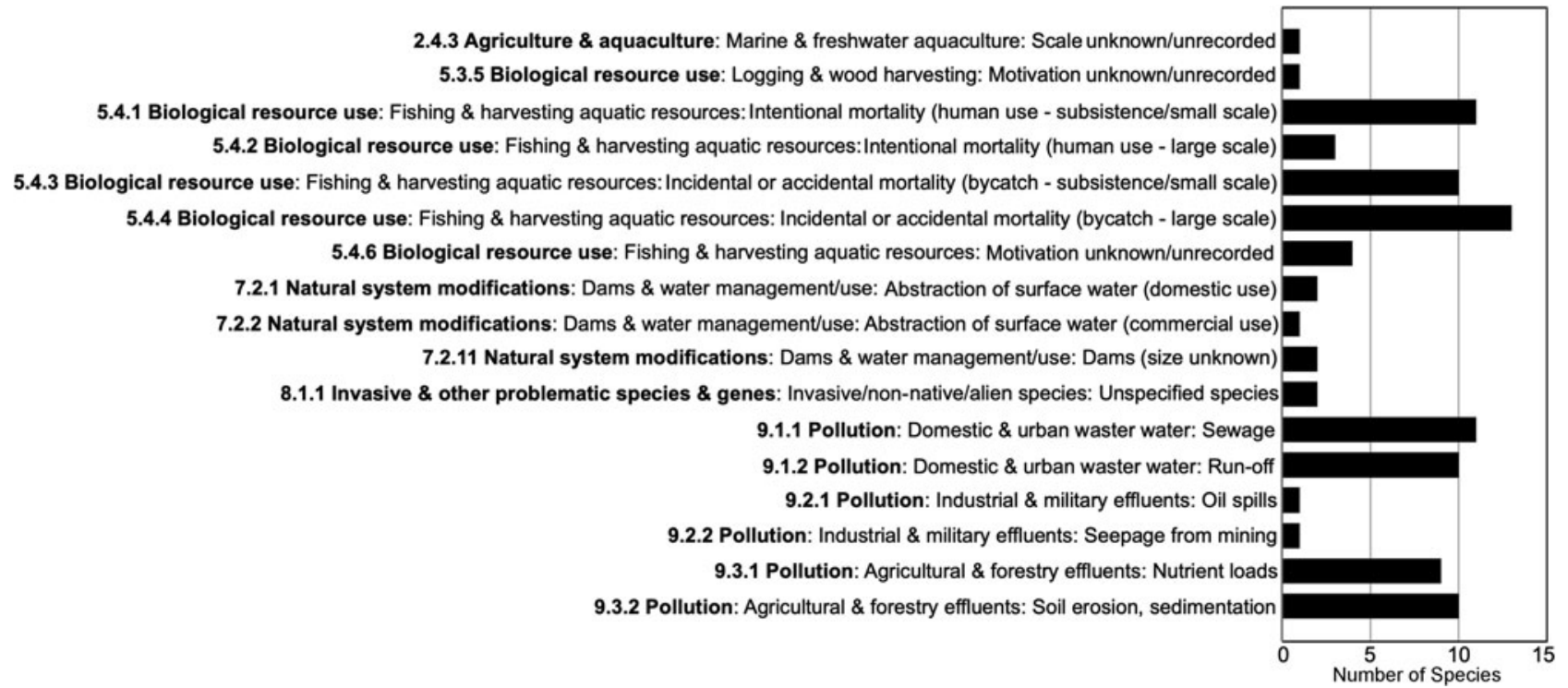

FIG. 1 Threats affecting threatened syngnathiform fishes, with the number of species affected. Numbers correspond to the hierarchical IUCN, Threats Classification Scheme (IUCN, 2012). Most species are affected by multiple threats. Marine species are primarily affected by exploitation; fresh- and brackish-water species by habitat loss and degradation.

TABLE 3 Number of syngnathiform species in each IUCN Red List category for all UN Food and Agriculture Organization (FAO) fishing areas and for Hippocampus, Microphis and freshwater species.

\begin{tabular}{|c|c|c|c|c|c|c|c|}
\hline \multirow[b]{2}{*}{ FAO area/subgroup } & \multicolumn{6}{|c|}{ Red List category $^{1}$} & \multirow[b]{2}{*}{ Total } \\
\hline & CR & EN & VU & $\mathrm{DD}$ & NT & $\mathrm{LC}$ & \\
\hline Northwest Atlantic & 0 & 0 & 1 & 0 & 0 & 10 & 11 \\
\hline $\begin{array}{l}\text { Western Central } \\
\text { Atlantic }\end{array}$ & 0 & 0 & 1 & 6 & 1 & 23 & 31 \\
\hline Southwest Atlantic & 0 & 0 & 2 & 3 & 1 & 17 & 23 \\
\hline Northeast Atlantic & 0 & 0 & 0 & 2 & 0 & 9 & 11 \\
\hline Mediterranean Sea & 0 & 0 & 0 & 8 & 0 & 8 & 16 \\
\hline $\begin{array}{l}\text { Eastern Central } \\
\text { Atlantic }\end{array}$ & 0 & 0 & 1 & 5 & 0 & 9 & 15 \\
\hline Southeast Atlantic & 1 & 1 & 1 & 1 & 0 & 9 & 13 \\
\hline $\begin{array}{l}\text { Western Indian } \\
\text { Ocean }\end{array}$ & 1 & 0 & 5 & 22 & 0 & 59 & 87 \\
\hline Eastern Indian Ocean & 0 & 0 & 8 & 29 & 0 & 99 & 136 \\
\hline Northwest Pacific & 0 & 0 & 6 & 13 & 0 & 46 & 65 \\
\hline $\begin{array}{l}\text { Western Central } \\
\text { Pacific }\end{array}$ & 0 & 1 & 8 & 38 & 0 & 82 & 129 \\
\hline Southwest Pacific & 0 & 1 & 1 & 8 & 0 & 35 & 45 \\
\hline Northeast Pacific & 0 & 0 & 0 & 0 & 0 & 4 & 4 \\
\hline $\begin{array}{l}\text { Eastern Central } \\
\quad \text { Pacific }\end{array}$ & 0 & 0 & 4 & 5 & 0 & 41 & 50 \\
\hline Southeast Pacific & 0 & 0 & 1 & 3 & 0 & 11 & 15 \\
\hline Hippocampus spp. & 0 & 2 & 12 & 17 & 1 & 10 & 42 \\
\hline Microphis spp. & 0 & 1 & 1 & 7 & 1 & 8 & 18 \\
\hline Freshwater spp. & 1 & 1 & 1 & 15 & 1 & 23 & 42 \\
\hline $\begin{array}{l}\text { Global } \\
\quad \text { (all Syngnathiformes) }\end{array}$ & 1 & 3 & 14 & 97 & 2 & 183 & 300 \\
\hline
\end{tabular}

${ }^{1} \mathrm{CR}$, Critically Endangered; EN, Endangered; VU, Vulnerable; DD, Data Deficient; NT, Near Threatened; LC, Least Concern. species will facilitate development of a Red List Index for the taxon, and for assessments under the new IUCN Green Status of Species, the criteria of which are used to measure conservation legacy and recovery potential (Akçakaya et al., 2018).

For the seahorses affected by fishing, effective conservation will require a concerted international effort to reduce exploitation in both non-selective and targeted fisheries, along with efforts to mitigate the effects of these fisheries on syngnathid habitats. A particular focus should be on curtailing bottom trawling; its indiscriminate and destructive nature leads to the extraction of tens of millions of seahorses annually and the destruction of benthic habitat (Lawson et al., 2017). Spatial and temporal fisheries closures are key to avoiding such destructive fishing (Dunn et al., 2011; Dichmont et al., 2013), with a particular focus on establishing wellimplemented zones or marine protected areas that exclude trawling. Regulating target fisheries for seahorses will require dialogue with small-scale and subsistence fishers. An adaptive management framework that emphasizes learning and refinement would be appropriate in this regard (Walters, 2007).

For the seahorses and pipefishes affected by habitat destruction, the focus needs to be on reducing and ameliorating destruction and degradation of critical habitats such as seagrasses, sponges and corals. For the freshwater and estuarine pipefishes, in particular, conservation requires a combination of naturalizing flow regimes, addressing pointsource pollution and nutrient influx, managing riverine and coastal development, and appropriately siting protected areas established within a whole-watershed framework. 
Such work is already underway in some areas, for example, in the Knysna Estuary, South Africa (de Villiers et al., 2019; Claassens et al., 2020).

It is vital to evaluate the impact of all conservation actions, and to modify them responsively. Robust long-term monitoring programmes are needed to evaluate population dynamics, fisheries, trade and habitat quality. Dedicated coastal surveys are needed, especially for those species with small ranges. Such surveys should occur over different seasons and times of day, and should start in localities with confirmed specimens or sightings, working outwards to adjacent areas with suitable habitat. All must be controlled for effort, whether hours invested or distance surveyed. Species that are not currently assessed as threatened should also be monitored closely to ensure that known pressures of exploitation and habitat damage-married to ecological shifts arising from the increasingly urgent threat resulting from climate change-do not lead them to become threatened. Community science is a valuable tool that can and is assisting in this endeavour (Haywood et al., 2016; Project Seahorse, unpubl. data, 2019).

Conservation action for syngnathiform fishes has the potential to benefit other species (Rodrigues \& Brooks, 2007; Shokri et al., 2009). Limiting fishing mortality, in particular by constraining bottom trawling and other non-selective fisheries, and ensuring healthy habitats is important both for the syngnathids and for other aquatic species. Given that the order is nearly global, there is potential for syngnathiformes, many of which are highly charismatic, to act as flagship species for ocean conservation.

Acknowledgements This is a contribution from Project Seahorse. We thank colleagues at Project Seahorse, the members of the IUCN Species Survival Commission Seahorse, Pipefish and Seadragon Specialist Group, and the IUCN Red List Unit for their insights and assistance. Lily Stanton sourced photographs, created figures and reviewed this research. Richard Smith (OceanRealmImages.com) and iNaturalist users provided photographs. David Harasti, Nuno Monteiro, Nick Dulvy and an anonymous reviewer critiqued the text. We thank the many volunteers and students at The University of British Columbia who helped gather and collate the information to drive these assessments: Daphne Austin, Lindsay Aylesworth, Claire Cameron, Cody Carlisle, Tíng-Chūn Kūo, Sarina Clay-Smith, Katelyn Dick, Hannah Fiegenbaum, Kyle Gillespie, Courtney Graham, Olivia Jamieson, Julia Lawson, Clayton Manning, Liria Nair, Thea Rachinski, Tanvi Vaidyanathan and Xiong Xhang. We thank the IUCN Red List Committee and Synchronicity Earth for financial support. Project Seahorse is supported by Guylian Chocolates (Belgium) in a partnership for marine conservation.

Author contributions Study design, data collection: RAP, ACJV; review and publication of assessments, data analysis, writing: all authors.

\section{Conflicts of interest None.}

Ethical standards This research abided by the Oryx guidelines on ethical standards. There were no human subjects, experimentation with animals, or collection of specimens associated with this work.

\section{References}

Aкçakaya, H.R., Bennett, E.L., Brooks, T.M., Grace, M.K., Heath, A., Hedges, S. et al. (2018) Quantifying species recovery and conservation success to develop an IUCN Green List of Species. Conservation Biology, 32, 1128-1138.

Arthington, A.H., Dulvy, N.K., Gladstone, W. \& Winfield, I.J. (2016) Fish conservation in freshwater and marine realms: status, threats and management. Aquatic Conservation: Marine and Freshwater Ecosystems, 26, 838-857.

BAUM, J.K. \& VinCENT, A.C.J. (2005) Magnitude and inferred impacts of the seahorse trade in Latin America. Environmental

Conservation, 32, 305-319.

Bennett, J.R., Maloney, R. \& Possingham, H.P. (2015) Biodiversity gains from efficient use of private sponsorship for flagship species conservation. Proceedings of the Royal Society B: Biological Sciences, 282, 20142693.

Betancur-R., R., Broughton, R.E., Wiley, E.O., Carpenter, K., López, J.A., Li, C. et al. (2013) The Tree of Life and a new classification of bony fishes. PLOS Currents Tree of Life, Edition 1.

Biodiversity Heritage Library (2021) biodiversitylibrary.org [accessed 30 June 2017].

Bland, L.M., Bielby, J., Kearney, S., Orme, C.D.L., Watson, J.E.M. \& Collen, B. (2017) Toward reassessing data-deficient species. Conservation Biology, 31, 531-539.

Bowen, B.W., Bass, A.L., Rocha, L.A., Grant, W.S. \& Robertson, D.R. (2001) Phylogeography of the trumpetfishes (Aulostomus): ring species complex on a global scale. Evolution, 55, 1029-1039.

Bowen-Jones, E. \& Entwistle, A. (2002) Identifying appropriate flagship species: the importance of culture and local contexts. Oryx, 36, 189-195.

Boyce, M.S. (1992) Population viability analysis. Annual Review of Ecology and Systematics, 23, 481-497.

Butchart, S.H.M., Stattersfield, A.J., Baillie, J., Bennun, L.A., STUART, S.N., АкÇАKaYA, H.R. et al. (2005) Using Red List Indices to measure progress towards the 2010 target and beyond. Philosophical Transactions of the Royal Society of London B: Biological Sciences, 360, 255-268.

Butchart, S.H.M., Akçakaya, H.R., Chanson, J., Baillie, J.E.M., Collen, B., Quader, S. et al. (2007) Improvements to the Red List Index. PLOS ONE, 2, e140.

Butchart, S.H.M., Walpole, M., Collen, B., van Strien, A., Scharlemann, J.P.W., Almond, R.E.A. et al. (2010) Global biodiversity: indicators of recent declines. Science, 328 , 1164-1168.

Caro, T. (2010) Conservation by Proxy: Indicator, Umbrella, Keystone, Flagship, and Other Surrogate Species. Island Press, Washington, DC, USA.

Carpenter, K.E., Abrar, M., Aeby, G., Aronson, R.B., Banks, S., BRUCKNER, A. et al. (2008) One-third of reef-building corals face elevated extinction risk from climate change and local impacts. Science, 321, 560-563.

Carpenter, S.R., Stanley, E.H. \& Vander Zanden, M.J. (2011) State of the world's freshwater ecosystems: physical, chemical, and biological changes. Annual Review of Environment and Resources, 36, 75-99.

Carrizo, S.F., Jähnig, S.C., Bremerich, V., Freyhof, J., Harrison, I., HE, F. et al. (2017) Freshwater megafauna: flagships for freshwater biodiversity under threat. BioScience, 67, 919-927.

Carvajal-Quintero, J.D., Januchowski-Hartley, S.R., Maldonado-Ocampo, J.A., Jézéquel, C., Delgado, J. \& Tedesco, P.A. (2017) Damming fragments species' ranges and heightens extinction risk. Conservation Letters, 10, 708-716. 
CBD (2010) Conference of the Parties to the Convention on Biological Diversity, Tenth Meeting, Nagoya, Japan, 18-29 October 2010. UNEP, Nagoya, Japan.

Claassens, L., Barnes, R.S.K., Wasserman, J., Lamberth, S.J., Miranda, N.A.F., van Niekerk, L. \& Adams, J.B. (2020) Knysna Estuary health: ecological status, threats and options for the future. African Journal of Aquatic Science, 45, 65-82.

Comeros-Raynal, M.T., Polidoro, B.A., Broatch, J., Mann, B.Q., Gorman, C., Buxton, C.D. et al. (2016) Key predictors of extinction risk in sea breams and porgies (Family: Sparidae). Biological Conservation, 202, 88-97.

Crain, C.M., Halpern, B.S., Beck, M.W. \& Kappel, C.V. (2009) Understanding and managing human threats to the coastal marine environment. Annals of the New York Academy of Sciences, 1162, 39-62.

Crain, C.M., Kroeker, K. \& Halpern, B.S. (2008) Interactive and cumulative effects of multiple human stressors in marine systems. Ecology Letters, 11, 1304-1315.

Dawson, C.E. (1985) Indo-Pacific Pipefishes: Red Sea to the Americas. Gulf Coast Research Laboratory, Ocean Springs, USA.

De Brauwer, M., Harvey, E.S., McIlwain, J.L., Hobbs, J.-P.A., Jompa, J. \& Burton, M. (2017) The economic contribution of the muck dive industry to tourism in Southeast Asia. Marine Policy, $83,92-99$.

de Villiers, N.M., Barker, C., Claassens, L. \& Hodgson, A.N. (2019) Conservation value of Codium tenue habitat for the endangered Knysna seahorse Hippocampus capensis. Journal of Fish Biology, 95, 1457-1464.

Dichmont, C.M., Ellis, N., Bustamante, R.H., Deng, R., Tickell, S., PASCUAL, R. et al. (2013) Evaluating marine spatial closures with conflicting fisheries and conservation objectives. Journal of Applied Ecology, 50, 1060-1070.

Dudgeon, D., Arthington, A.H., Gessner, M.O., Kawabata, Z.-I., KNowler, D.J., Lévêque, C. et al. (2006) Freshwater biodiversity: importance, threats, status and conservation challenges. Biological Reviews, 81, 163-182.

Dulvy, N.K., Sadovy, Y. \& Reynolds, J.D. (2003) Extinction vulnerability in marine populations. Fish and Fisheries, 4, 25-64.

Dunn, D.C., Boustany, A.M. \& Halpin, P.N. (2011) Spatio-temporal management of fisheries to reduce by-catch and increase fishing selectivity. Fish and Fisheries, 12, 110-119.

ENCYCLOPEDIA OF LIFE (EOL) (2021) eol.org [accessed 30 June 2017].

Foster, S.J. \& Vincent, A.C.J. (2004) Life history and ecology of seahorses: implications for conservation and management. Journal of Fish Biology, 65, 1-61.

Frankham, R., Bradshaw, C.J.A. \& Brook, B.W. (2014) Genetics in conservation management: revised recommendations for the 50/500 rules, Red List criteria and population viability analyses. Biological Conservation, 170, 56-63.

Fricke, R., Eschmeyer, W.N. \& VAN Der LaAn, R. (eds) (2020) Eschmeyer's Catalog of Fishes: Genera, Species, References. researcharchive.calacademy.org/research/ichthyology/catalog/ fishcatmain.asp [accessed 13 November 2020].

Froese, R. \& Pauly, D. (eds) (2019) FishBase. fishbase.org [accessed December 2019].

GBif (The Global Biodiversity Information Facility) (2020) What is GBIF? gbif.org/what-is-gbif [accessed 13 November 2020].

Halpern, B.S., Frazier, M., Potepenko, J., Casey, K.S., Koenig, K., Longo, C. et al. (2015) Spatial and temporal changes in cumulative human impacts on the world's ocean. Nature Communications, 6,7615 .

Hamilton, H., Saarman, N., Short, G., Sellas, A.B., Moore, B., HoANG, T. et al. (2017) Molecular phylogeny and patterns of diversification in syngnathid fishes. Molecular Phylogenetics and Evolution, 107, 388-403.
Harasti, D. (2016) Declining seahorse populations linked to loss of essential marine habitats. Marine Ecology Progress Series, 546, 173-181.

Harasti, D., Martin-Smith, K. \& Gladstone, W. (2014) Ontogenetic and sex-based differences in habitat preferences and site fidelity of the White's seahorse Hippocampus whitei. Journal of Fish Biology, 85, 1413-1428.

Haywood, B.K., Parrish, J.K. \& Dolliver, J. (2016) Place-based and data-rich citizen science as a precursor for conservation action. Conservation Biology, 30, 476-486.

Hoffmann, M., Duckworth, J.W., Holmes, K., Mallon, D.P., Rodrigues, A.S.L. \& Stuart, S.N. (2015) The difference conservation makes to extinction risk of the world's ungulates. Conservation Biology, 29, 1303-1313.

Hoffmann, M., Hilton-Taylor, C., Angulo, A., Böhm, M., Brooks, T.M., Butchart, S.H.M. et al. (2010) The impact of conservation on the status of the world's vertebrates. Science, 330, 1503-1509.

Hughes, A.R., Williams, S.L., Duarte, C.M., Heck, K.L. \& WA с сотт, M. (2009) Associations of concern: declining seagrasses and threatened dependent species. Frontiers in Ecology and the Environment, 7, 242-246.

Hutchings, J.A. \& Reynolds, J.D. (2004) Marine fish population collapses: consequences for recovery and extinction risk. BioScience, 54, 297-309.

IUCN (2012) IUCN Red List Categories and Criteria: Version 3.1, 2nd edition. Gland, Switzerland and Cambridge, UK.

IUCN (2020) IUCN Red List of Threatened Species. Version 2020-1. iucnredlist.org [accessed 3 May 2020].

IUCN Standards and Petitions Subcommittee (2017) Guidelines for Using the IUCN Red List Categories and Criteria. Version 13. Standards and Petitions Subcommittee, Gland, Switzerland and Cambridge, UK.

Kawahara, R., Miya, M., Mabuchi, K., Lavoué, S., Inoue, J.G., $\mathrm{S}_{\mathrm{ATOH}}$, T.P. et al. (2008) Interrelationships of the 11 gasterosteiform families (sticklebacks, pipefishes, and their relatives): a new perspective based on whole mitogenome sequences from 75 higher teleosts. Molecular Phylogenetics and Evolution, 46, 224-236.

Kindsvater, H.K., Dulvy, N.K., Horswill, C., Juan-Jordá, M.-J., Mangel, M. \& Matthiopoulos, J. (2018) Overcoming the data crisis in biodiversity conservation. Trends in Ecology and Evolution, 33, 676-688.

Kopf, R.K., Shaw, C. \& Humphries, P. (2017) Trait-based prediction of extinction risk of small-bodied freshwater fishes. Conservation Biology, 31, 581-591.

Krumhansl, K.A., OKamoto, D.K., Rassweiler, A., NovaK, M., Bolton, J.J., Cavanaugh, K.C. et al. (2016) Global patterns of kelp forest change over the past half-century. Proceedings of the National Academy of Sciences of the United States of America, 113, 13785-13790.

Kuiter, R.H. (2009) Seahorses and Their Relatives. Aquatic Photographics, Seaford, Australia.

Lawson, J.M., Foster, S.J. \& Vincent, A.C. (2017) Low bycatch rates add up to big numbers for a genus of small fishes. Fisheries, 42, 19-33.

Longo, S.J., Faircloth, B.C., Meyer, A., Westneat, M.W., Alfaro, M.E. \& Wainwright, P.C. (2017) Phylogenomic analysis of a rapid radiation of misfit fishes (Syngnathiformes) using ultraconserved elements. Molecular Phylogenetics and Evolution, $113,33-48$.

Lotze, H.K., Lenihan, H.S., Bourque, B.J., Bradbury, R.H., Coокe, R.G., Kay, M.C. et al. (2006) Depletion, degradation, and recovery potential of estuaries and coastal seas. Science, 312, 1806-1809.

Lourie, S.A. (2016) Seahorses: A Life-Size Guide to Every Species. Ivy Press, East Sussex, UK. 
Lourie, S.A., Pollom, R.A. \& Foster, S.J. (2016) A global revision of the seahorses Hippocampus Rafinesque 1810 (Actinopterygii: Syngnathiformes): taxonomy and biogeography with recommendations for further research. Zootaxa, 4146, 1-66.

Mace, G.M., Collar, N.J., Gaston, K.J., Hilton-Taylor, C., AкÇAкaya, H.R., Leader-Williams, N. et al. (2008) Quantification of extinction risk: IUCN's system for classifying threatened species. Conservation Biology, 22, 1424-1442.

McClanahan, T., Allison, E.H. \& Cinner, J.E. (2015) Managing fisheries for human and food security. Fish and Fisheries, $16,78-103$.

Meeunig, J.J., Hoang, D.H., Ky, T.S., Job, S.D. \& Vincent, A.C.J. (2006) Quantifying non-target seahorse fisheries in central Vietnam. Fisheries Research, 81, 149-157.

Near, T.J., Dornburg, A., Eytan, R.I., Keck, B.P., Smith, W.L., Kunn, K.L. et al. (2013) Phylogeny and tempo of diversification in the superradiation of spiny-rayed fishes. Proceedings of the National Academy of Sciences of the United States of America, 110, 12738-12743.

Nelson, J.S., Grande, T.C. \& Wilson, M.V.H. (2016) Fishes of the World. 5th edition. John Wiley and Sons, Inc., Hoboken, USA.

O'Donnell, K.P., Pajaro, M.G. \& Vincent, A.C.J. (2010) How does the accuracy of fisher knowledge affect seahorse conservation status? Animal Conservation, 13, 526-533.

Perante, N.C., Pajaro, M.G., Meeuwig, J.J. \& Vincent, A.C.J. (2002) Biology of a seahorse species, Hippocampus comes in the central Philippines. Journal of Fish Biology, 60, 821-837.

Perry, A.L., Lunn, K.E. \& Vincent, A.C.J. (2010) Fisheries, large-scale trade, and conservation of seahorses in Malaysia and Thailand. Aquatic Conservation: Marine and Freshwater Ecosystems, 20, 464-475.

Polidoro, B.A., Carpenter, K.E., Collins, L., Duke, N.C., Ellison, A.M., Ellison, J.C. et al. (2010) The loss of species: mangrove extinction risk and geographic areas of global concern. PLOS ONE, 5, e10095.

Poss, S.G. \& Heal, E. (1994) The scientific publications of Charles Eric Dawson (1948-1990). Gulf Research Reports, 9, 69-73.

Reynolds, J.D., Dulvy, N.K., Goodwin, N.B. \& Hutchings, J.A. (2005) Biology of extinction risk in marine fishes. Proceedings of the Royal Society B: Biological Sciences, 272, 2337-2344.

Rodrigues, A.S.L. \& BROOKS, T.M. (2007) Shortcuts for biodiversity conservation planning: the effectiveness of surrogates. Annual Review of Ecology, Evolution, and Systematics, 38, 713-737.

Sanciangco, J.C., Carpenter, K.E., Etnoyer, P.J., Moretzsohn, F. \& DufF, G. (2013) Habitat availability and heterogeneity and the Indo-Pacific warm pool as predictors of marine species richness in the tropical Indo-Pacific. PLOS ONE, 8, e56245.

Sanciangco, M.D., Carpenter, K.E. \& Betancur-R., R. (2016) Phylogenetic placement of enigmatic percomorph families
(Teleostei: Percomorphaceae). Molecular Phylogenetics and Evolution, 94, 565-576.

Scales, H. (2009) Poseidon's Steed: The Story of Seahorses, From Myth to Reality. Gotham Books, New York, USA.

Shokri, M.R., Gladstone, W. \& Jelbart, J. (2009) The effectiveness of seahorses and pipefish (Pisces: Syngnathidae) as a flagship group to evaluate the conservation value of estuarine seagrass beds. Aquatic Conservation: Marine and Freshwater Ecosystems, 19, 588-595.

Short, F.T., Polidoro, B., Livingstone, S.R., Carpenter, K.E., Bandeira, S., Bujang, J.S. et al. (2011) Extinction risk assessment of the world's seagrass species. Biological Conservation, 144, 1961-1971.

Short, G., Claassens, L., Smith, R., De Brauwer, M., Hamilton, H., Stat, M. \& Harasti, D. (2020) Hippocampus nalu, a new species of pygmy seahorse from South Africa, and the first record of a pygmy seahorse from the Indian Ocean (Teleostei, Syngnathidae). ZooKeys, 934, 141-156.

Song, H.Y., Mabuchi, K., Satoh, T.P., Moore, J.A., Yamanoue, Y., MiYa, M. \& NishidA, M. (2014) Mitogenomic circumscription of a novel percomorph fish clade mainly comprising "Syngnathoidei" (Teleostei). Gene, 542, 146-155.

Stiller, J., Wilson, N.G., Donnellan, S. \& Rouse, G.W. (2017) The leafy seadragon, Phycodurus eques, a flagship species with low but structured genetic variability. The Journal of Heredity, 108, 152-162.

Stuart, S.N., Wilson, E.O., McNeely, J.A., Mittermeier, R.A. \& Rodríguez, J.P. (2010) The barometer of life. Science, 328, 177.

Vincent, A.C.J., Foster, S.J. \& Koldewey, H.J. (2011) Conservation and management of seahorses and other Syngnathidae. Journal of Fish Biology, 78, 1681-1724.

Walpole, M.J. \& Leader-Williams, N. (2002) Tourism and flagship species in conservation. Biodiversity and Conservation, $11,543-547$.

WAlters, C.J. (2007) Is adaptive management helping to solve fisheries problems? AMBIO: A Journal of the Human Environment, $36,304-307$.

Waltham, N.J. \& Connolly, R.M. (2011) Global extent and distribution of artificial, residential waterways in estuaries. Estuarine, Coastal and Shelf Science, 94, 192-197.

Waycott, M., Duarte, C.M., Carruthers, T.J.B., Orth, R.J., Dennison, W.C., Olyarnik, S. et al. (2009) Accelerating loss of seagrasses across the globe threatens coastal ecosystems. Proceedings of the National Academy of Sciences, 106, 12377-12381.

Weвв, T.J. \& MindeL, B.L. (2015) Global patterns of extinction risk in marine and non-marine systems. Current Biology, 25, 506-511.

Wilson, A.B. \& ORR, J.W. (2011) The evolutionary origins of Syngnathidae: pipefishes and seahorses. Journal of Fish Biology, $78,1603-1623$.

ZHANG, X. \& VinCENT, A.C.J. (2019) Using cumulative-humanimpact models to reveal global threat patterns for seahorses (Hippocampus spp.). Conservation Biology, 33, 1380-1391. 